\title{
WRONGFUL BIRTH, WRONGFUL CONCEPTION, AND THE IRISH CONSTITUTION
}

\section{Introduction}

This paper examines the question of whether, based on the current legal situation, a claim for compensation in wrongful birth and wrongful conception cases would be successful in the Republic of Ireland. It begins with an outline of what is commonly understood by the terms 'wrongful birth' and 'wrongful conception'. Brief analysis will then be provided of the judiciary's approach in the United Kingdom. ${ }^{1}$ Specifically, the focus of the work examines how the existence of a Constitution in the Republic of Ireland, which guarantees the right to life of the unborn child, could influence the potential issue of compensation in such cases. Evaluation of existing Irish case law on the issue of abortion and the right to life suggests that the Irish judiciary would find it difficult to reconcile payment of compensation for the upbringing of a child because of the positive duty incumbent upon the State to protect the right to life. ${ }^{2}$

\section{Distinguishing 'wrongful birth' and 'wrongful conception'}

The terms 'wrongful birth' and 'wrongful conception' should not be taken as different tags for the same issue. There has been disparity and confusion regarding this matter which has inevitably led to confusion as to the proper use of terminology. ${ }^{3}$ In McFarlane, Lord Steyn defines 'wrongful birth' actions as those taken by parents for the damage they suffer due to this 'unwanted' birth. ${ }^{4}$ Lord Clyde in the same case adopts a different view as to the meaning of 'wrongful conception' and 'wrongful birth' stating that the claim in McFarlane is for wrongful conception, not wrongful birth where negligence has failed to terminate the child. ${ }^{5}$

Academic commentary further illustrates the various interpretations relating to the two terms under review. Donnelly provides a more precise qualification, explaining that:

Wrongful birth arises where a child is born due to negligence in the performance of an abortion or where the defendant has failed to warn the parents that the

\footnotetext{
${ }^{1}$ Focusing in particular on the seminal decision in McFarlane v. Tayside Health Board [1999] 3 W.L.R. 1301

${ }^{2}$ Such a position will inevitably be influenced by the Constitutional provisions and by the notion of prudence, justice and charity rather than notions of 'distributive justice' alongside consideration of the ubiquitous person who avails of London transport systems. Laura Hoyano is somewhat critical of the English courts approach to such cases, and calls for the judiciary to 'directly confront policy factors...rather than relinquishing that formidable task to the passenger on the London Underground'. See Hoyano, L. 'Misconceptions about Wrongful Conception', Modern Law Review, 2002, 65(6): 883-906

${ }^{3}$ Evidence of this occurs in a number of cases that arose in England in the 1980s, namely Udale $v$ Bloomsbury Area Health Authority, ${ }^{3}$ Sciuragia v Powell, ${ }^{3}$ Emeh $v$ Kensington and Chelsea and Westminster Area Health Authority, Thake v Maurice, Gold v Haringey Health Authority, as these cases could now be categorised as wrongful conception as they were the result of failed sterilisations and not due to the failure to identify abnormalities during antenatal screening.

${ }^{4}$ McFarlane v. Tayside Health Board [1999] 3 W.L.R. 1301 at 1313

${ }^{5}$ Ibid. at 1334
} 
unborn child suffers from a handicap thus depriving them of the chance of having an abortion. ${ }^{6}$

In Symmons' discussion on informed consent and wrongful birth, it is quite apparent that he understands wrongful birth cases to mean those arising where a child is born after a sterilisation procedure has failed. ${ }^{7}$ Indeed the very cases in Symmons analysis could more correctly be categorised as 'wrongful conception' as they do not all involve the birth of a child with disabilities following failed antenatal screening, where the parents have been denied the option of an abortion.

Defining 'wrongful conception' as meaning those cases resulting in the birth of a child due to a failed sterilisation and 'wrongful birth' as cases brought by the parents of a disabled child born as a result of a failure to detect the congenital abnormality at the antenatal screening stage has implications for the viability of claims that may be instigated in Ireland under either of these headings.

\section{Wrongful Conception and Wrongful Birth Cases in the UK Courts}

From the Court of Appeal decision in Emeh v. Kensington and Chelsea and Westminster Area Health Authority, ${ }^{8}$ to the House of Lords ruling in McFarlane v. Tayside Health Board, ${ }^{9}$ public policy arguments have consistently been deployed by the respective courts to either permit or refuse recovery of damages for wrongful birth and wrongful conception cases.

In Emeh, the Court of Appeal held that damages were recoverable for loss of future earnings and the maintenance of the child. ${ }^{10}$ The Health Authority put forward the public policy argument as grounds for preventing the recovery of damages for maintenance of a child. However, Waller LJ rejected these stating that he did not find the Health Authority's 'public policy objection convincing', and that if damages could not be recovered on the grounds of public policy that this could encourage some mothers to decide to have an abortion even at a very late stage of the pregnancy. ${ }^{11}$ Purchas LJ also rejected the public policy arguments on the basis that it is the responsibility of Parliament to provide for such situations and not the courts. ${ }^{12}$ As such, the three judges held that

\footnotetext{
${ }^{6}$ Donnelly, M. (1997) 'The injury of parenthood: the tort of wrongful conception', Northern Ireland Legal Quarterly, Vol.48, No.1 p.10

${ }^{7}$ Symmons, C. 'The problem of 'informed consent' in the 'wrongful birth' cases', Professional Negligence, 1987, 3(2):56-62

${ }^{8}$ [1984] 3 All ER 1044

9 [1999] 3 W.L.R. 1301

${ }^{10}$ This case arose as a result of a negligent sterilisation operation. The plaintiff became pregnant after the sterilisation and refused to terminate the pregnancy, subsequently giving birth to a child with congenital disabilities. Damages were sought for loss of future earnings, maintenance of the child, pain and suffering and loss of amenity, as well as damages for the extra care that the child would need. The trial judge deemed the plaintiff's failure to have an abortion to amount to a novus actus interveniens, and awarded only damages covering pain and suffering of the plaintiff up to the time that she discovered the pregnancy, and for having to undergo another sterilisation operation.

${ }^{11}$ Per Waller LJ in Emeh v. Kensington AHA [1984] 3 All ER 1044 at 1054-1055

${ }^{12}$ Emeh v. Kensington AHA [1984] 3 All ER 1044 at 1055
} 
there were no grounds of public policy to prevent the plaintiff recovering damages for loss of future earnings, maintenance of the child up to trial, future maintenance, pain and suffering until the trial and future loss of amenity and pain and suffering, including the extra care that the child would require. No distinction was made between a healthy or abnormal child with the court in Emeh recognising both wrongful birth and wrongful conception as forms of damage requiring compensation. ${ }^{13}$ For fifteen years the law was settled in this area, essentially that damages were recoverable for wrongful conception and wrongful birth.

Only the judgment in Udale v. Bloomsbury Area Health Authority ${ }^{14}$ is at variance with the other pre-McFarlane decisions. ${ }^{15}$ Here it was held that maintenance for raising a child until the age of sixteen was not recoverable on the grounds of public policy. These grounds are that it is 'undesirable' for a court to declare that a child's birth is an unwanted mistake; the benefits of a birth would outweigh any burdens; it would encourage late abortions if compensation were granted; and that the birth of a child is a 'blessing'. 16

Other cases concerning wrongful birth claims are similar to that of Emeh. In Thake v. Maurice ${ }^{17}$ Kerr LJ states that there 'is no such rule of public policy' that damages cannot be awarded for the birth of a healthy child. ${ }^{18}$ In Gold v. Haringey Health Authority ${ }^{19}$ it was clearly stated by Lloyd LJ that this case was not concerned with the issue of entitlement to damages for the birth of a healthy child, ${ }^{20}$ as he states that this matter had been settled by the court in Emeh. ${ }^{21}$ It is apparent that there was strong judicial consensus in the fifteen years prior to the House of Lords decision in McFarlane that there existed no public policy grounds to prevent recovery of damages for the birth of a healthy child, Udale being the only exception to this. That said it is worth mentioning that a sense of discomfort is evident in judicial decisions where cases concerning the award of damages for the birth and upbringing of a child are made, especially where the

\footnotetext{
${ }^{13}$ McLean, A. (2000) 'McFarlane v Tayside Health Board: A Wrongful Conception in the House of Lords?' Web Journal of Current Legal Issues Issue 3

${ }^{14}$ [1983] 2 All ER 522

${ }^{15}$ Counsel for the defence in Udale put forward a number of public policy reasons as to why damages should not be awarded. The Court went onto consider these public policy arguments leading to the conclusion that damages would be recoverable for the pain, suffering, inconvenience, anxiety and the disruption to the family's finances due to the unexpected pregnancy, as well as loss of earnings.

${ }^{16}$ Per Jupp J. Udale v. Bloomsbury Area Health Authority [1983] 2 All ER 522 at 531

${ }^{17}$ [1986] 1 All ER 497

${ }^{18}$ [1986] 1 All ER 497 at 500. Dealing with the plaintiff's cross-appeal for damages for pain and suffering, Kerr LJ refers on several occasions to the 'joy' of having a healthy child. The plaintiffs were entitled to claim damages for the pain and suffering of giving birth to a healthy child as it was held that the birth of a healthy child did not wipe out this pain and suffering.

${ }^{19}$ Gold v. Haringey Health Authority [1988] 1 Q.B. 481- this case again related to failure to warn that fertility could be restored after sterilisation.

${ }^{20}$ Gold v. Haringey Health Authority [1988] 1 Q.B. 481 at 484. Lloyd LJ refers to the unreported case of Jones v. Berkshire Area Health Authority,(unreported) 2 July 1986, noted in Gold v. Haringey Health Authority [1988] 1 Q.B. 481 at 484, and in particular that the rhetoric used in the case refers to the notion of the birth of a healthy child being a 'blessing'.

${ }^{21}$ Emeh v. Kensington AHA [1984] 3 All ER 1044
} 
child is 'healthy'. ${ }^{22}$ Although as MacLean asserts it would be difficult for the courts to make the argument that a pregnancy could not be unwanted due to the prevalent use of fertility control techniques. ${ }^{23}$

\section{The House of Lords and wrongful birth/wrongful conception claims}

In McFarlane v. Tayside Health Board ${ }^{24}$, the House of Lords relying upon principles of corrective and distributive justice decided that damages were not recoverable by the parents of a healthy child born as a result of a negligent sterilisation. Lord Slynn considered it not to be "fair, just or reasonable to impose on the doctor or his employer liability for the consequential responsibilities, imposed on or accepted by the parents to bring up a child.” ${ }^{25}$ In addition to policy considerations, Lord Steyn emphasised that such cases should be considered in terms of 'distributive justice'. ${ }^{26}$ Lord Clyde echoes this, stating the recovery is not permissible on the grounds of fairness and reasonableness. ${ }^{27}$

This decision of the House of Lords changed the existing legal landscape relating to such cases. In her criticism of the House of Lords decision Hoyano was of the view that if there was a need to change the stance taken by the courts in the cases dealt with in the previous fifteen years that Parliament would already have done so. As a result the fact that Parliament had not legislated on this matter would indicate that it did not deem it necessary to do so. ${ }^{28}$ The lack of unanimity on the part of the House of Lords in McFarlane has not provided clarification for future cases and has simply led to distinctions being made in subsequent cases. This was clear in Parkinson v. St James and Seacroft University Hospital NHS Trust as it was concluded that the parents of a disabled child would have a claim to the additional costs of rearing the child. ${ }^{29}$ What becomes apparent in this judgment is that there is not one 'correct' test applicable to all cases, as Brooke LJ stressed in his decision attributing the difficulties of applying the House of

\footnotetext{
22 Lord Clyde in his judgment in McFarlane v. Tayside Health Board [1999] 3 W.L.R. 1301 at p.1345 expressed his view that: 'There is something distasteful, if not morally offensive, in treating the birth of a normal, healthy child as a matter for compensation.'

${ }^{23}$ MacLean, A. (2000) 'McFarlane v Tayside Health Board: A Wrongful Conception in the House of Lords?' Web Journal of Current Legal Issues http://webjcli.ncl.ac.uk/2000/issue3/maclean3.html [Date accessed 01/07/2003]. Sterilisation in the United Kingdom is available not solely for therapeutic purposes; rather it is also an option for the purpose of limiting the size of one's family.

${ }^{24}$ McFarlane v. Tayside Health Board [1999] 3 W.L.R. 1301

${ }^{25}$ McFarlane v. Tayside Health Board [1999] 3 W.L.R. 1301 at 1312

${ }^{26}$ McFarlane v. Tayside Health Board [1999] 3 W.L.R. 1301 at 1319

${ }^{27}$ McFarlane v. Tayside Health Board [1999] 3 W.L.R. 1301 at 1340

${ }^{28}$ Hoyano, L. 'Misconceptions about Wrongful Conception', Modern Law Review, 2002, 65(6): 883-906 at 890 Hoyano highlights that although the Law Lords identified that there was no duty of care, a lack of consensus on the issues was evident. She notes that Lord Slynn refers to the lack of assumption of responsibility; Lord Hope states that it would not be fair, just or reasonable as there would be a lack of proportionality between liability and fault; and Lord Steyn submits that on the grounds of distributive justice, it would not be fair, just and reasonable.

${ }^{29}$ [2001] 3 All ER 97. This was the first wrongful conception case to reach the Court of Appeal after the House of Lords decision. It arose due to the negligent performance of a sterilisation operation. The plaintiff's claim was for damages for the upbringing of a child with behavioural problems.
} 
Lords ruling to wrongful conception cases to the absence of a united voice from the House of Lords. ${ }^{30}$

In addition to highlighting the difficulties with the application of the McFarlane decision to subsequent cases, also notable are the comments of Lady Justice Hale in dealing with the issue of parental responsibility. She stresses that the mother has automatic parental responsibility for the child as she gives birth to the child and will have a legal duty towards the child, emphasising that this parental responsibility goes beyond mere financial provision. ${ }^{31}$ Lady Justice Hale continues by holding that the benefits of a healthy child cancel out the costs involved in rearing the child. ${ }^{32}$ Thus even in those cases in which the parents have actively sought sterilisation as a means of preventing pregnancy in the first instance (as they do not wish to assume such parental responsibilities) a claim for compensation will not succeed.

A slight variation on this is evident in Rees v. Darlington Memorial Hospital NHS Trust ${ }^{33}$ even though it arises as a result of the birth of a child after a sterilisation procedure has failed. The plaintiff in this case is disabled, and her disability, a severe visual impairment, was the reason for her seeking sterilisation in the first instance, as she did not feel capable of looking after a child properly. At the Court of Appeal hearing, the majority held that she could claim damages for the extra costs of bringing up her child due to her disability so that she will be in the same position as parents without any such disabilities. Dissenting, Waller LJ was adamant that such claims should not be recoverable as set out in McFarlane, ${ }^{34}$ voicing reasons of fairness and distributive justice for his objection:

The House of Lords have since reversed this decision, concluding that parents could not recover damages for the birth of a healthy child as a result of a negligent sterilisation. Such a conclusion allowed for some degree of reconciliation of the law relating to wrongful conception and wrongful birth cases in the United Kingdom. However, the Law Lords proposed that they should "add a gloss to the decision in McFarlane's case", although this is not intended to reflect "the financial consequences of the birth of a

\footnotetext{
${ }^{30}$ Parkinson v. St James and Seacroft University Hospital NHS Trust [2001] 3 All ER 97 at 106-107

${ }^{31}$ Per Hale LJ Parkinson v. St James and Seacroft University Hospital NHS Trust [2001] 3 All ER 97 at 116 Hale LJ goes further to explain that the mother can arrange for this legal responsibility to be carried out by others.

${ }^{32}$ Wicks, R. (2001) 'Family Law - Wrongful Conception and Wrongful Birth’, Current Law Week, Vol.9(41). See Parkinson v. St James and Seacroft University Hospital NHS Trust [2001] 3 All ER 97 per Hale LJ at 122

33 [2002] 2 All ER 177

34 Waller LJ in Rees v. Darlington Memorial Hospital NHS Trust [2002] 2 All ER 177 at 190: 'The costs of recovering the expenses of looking after a healthy child born through the negligence of a surgeon, are costs which the court has said should not be recovered, and if that is the boundary that a court has set, it is important that the court does not make exceptions to that rule, which would seem unjust to the persons unable to recover as a result of that rule.'
} 
normal, healthy child, ${ }^{35}$ It is the introduction of this conventional award that will be the subject of future decisions. ${ }^{36}$

\section{$\underline{\text { 5. Viability of Wrongful Conception and Wrongful Birth Actions in Ireland }}$}

To date no cases have appeared before the Irish courts relating to this matter. In the event that such a case does arise the courts will be asked to regulate in the absence of legislation outlining the legal position. ${ }^{37}$

One of the first issues to be addressed within the Irish context is whether it is possible that a claim for damages due to wrongful conception could arise. ${ }^{38}$ Donnelly submits that the likelihood of a tort of wrongful conception emerging is dependent upon the free availability of contraception. ${ }^{39}$ Contraception and contraceptive practices in Ireland have very much been influenced by the ethos and teachings of the Catholic Church. ${ }^{40}$ Contraception was not legally available until 1979, a position which was at variance with that in the United Kingdom. Not only was contraception legally available in the United Kingdom, it is acknowledged that family planning was generally practised, to the extent that some methods of family planning, namely vasectomy, were made available under the National Health Service. ${ }^{41}$ Contrast this with the position in the Republic of Ireland where a woman had to take a case through the courts arguing that under the Constitution, she had a personal right to privacy that allowed her to use contraceptives within marriage. ${ }^{42}$ As a result of this decision, the right to limit the size of one's family remains

\footnotetext{
${ }^{35}$ This 'gloss' is a conventional award of $£ 15,000$ in recognition of the legal wrong suffered by the parents as they have lost their right to choose to limit the size of their family. Per Lord Nicholls, Rees v. Darlington Memorial Hospital NHS Trust [2003] 4 All ER 987 at 995, and per Lord Millett, at 1025

${ }^{36}$ Dixon, C. “An unconventional gloss on unintended children” New Law Journal 21 November 2003, p.1732-1733

${ }^{37}$ Indeed the Irish judiciary have in previous abortion cases stressed that they will be proactive in the absence of legislation. In the Attorney-General v. X [1992] 1 IR 1 . One of the defendant's grounds for appeal was that the courts were "inhibited from exercising a function to vindicate and defend the right to life of the unborn which is identified and guaranteed by Article 40, s.3, sub-s.3 of the Constitution by reason of a want of legislation”. Finlay C.J. held that the power of the court was not in anyway inhibited by a lack of legislation and dismissed this ground of appeal. In his judgment in the X case, Hederman J. emphasizes that where: "the Oireachtas had not enacted any law purporting to regulate the manner in which the right to life of the unborn and the right to life of the mother referred to in the Eighth Amendment should be reconciled, the Court has jurisdiction to make such orders as it thinks proper to give effect to the Amendment. In the absence of legislation not in conflict with the Constitution it must fall to the Court pursuant to Article 40, s. 3, sub-s. 3 to reconcile the conflict between the right to life of the unborn and the right to life of the mother."

${ }^{38}$ For the purposes of this article, wrongful conception claims relates to those cases which result in the birth of a child due to a failed sterilisation.

${ }^{39}$ Donnelly, M. (1997) 'The injury of parenthood: the tort of wrongful conception', Northern Ireland Legal Quarterly, Vol.48, No.1 p.10 at p.22

${ }^{40}$ Mahon, E., Conlon, C. \& Dillon, L.,(1998), Women and Crisis Pregnancy: A Report Presented to the Department of Health and Children, Dublin: The Stationery Office, p.19

${ }^{41}$ Per Pain J. at first instance in Thake v. Maurice [1984] 2 WLR 215 at 230. Pain J. submitted that the availability of such methods of family planning indicated that 'the birth of a healthy child is not always a blessing.'

${ }^{42}$ McGee v. Attorney General [1974] I.R. 284
} 
with the individuals concerned. Subsequent to the Supreme Court ruling in this case, contraception was eventually made available with the introduction of the Health (Family Planning) Act 1979, permitting the issue of contraception on prescription for family planning purposes or for medical reasons. Availability of contraception has been subject to strict regulation within Ireland; indeed the sale of condoms without prescription from named outlets was only permissible after the 1985 amendments to the Health (Family Planning) Act $1979 .{ }^{43}$ Liberalisation of the sale of condoms in Ireland has had more to do with public health concerns due to the spread of the AIDS virus and the need to promote safe sex practises rather than provision of contraceptive measures to prevent conception and so-called 'unwanted' pregnancies. ${ }^{44}$ Family planning services provided for by the health boards only became legally available with further amendments to the legislation, the Health (Family Planning)(Amendment) Act $1992 .{ }^{45}$

There is no statutory regulation of sterilisation. ${ }^{46}$ Sterilisation is available in the Republic of Ireland, as a method of contraception now, although it is restricted either for reasons of costs or lack of availability in certain health board areas. ${ }^{47}$ In fact it is asserted that sterilisation is only acceptable in those situations where "it will benefit the life or health of the individual". ${ }^{48}$ There are conflicting messages within the healthcare profession about the use of sterilisation in Ireland. Some sources have indicated that it is much more freely available than it would have been a decade ago, but the context in which it is used remains one relating to the life or health of the individual. Other sources claim that sterilisation is fairly readily available as a method of contraception, and that sterilisation would be refused only if the woman was very young or has no children. ${ }^{49}$ It is notable that in the report presented to the Department of Health and Children in Ireland, 'Women and Crisis Pregnancy', among the findings on contraceptive practices included the case of a group of women who sought sterilisation as means of preventing pregnancy but were not sterilised for one of two reasons. These reasons being that sterilisation was not available at their local hospital or that some women did not want to proceed with the sterilisation without their husband's consent. ${ }^{50}$

\footnotetext{
${ }^{43}$ The Health (Family Planning) Act 1992 increased the number of outlets through which contraceptives could be sold.

${ }^{44}$ Mahon, E., Conlon, C. \& Dillon, L., (1998), Women and Crisis Pregnancy: A Report Presented to the Department of Health and Children, Dublin: The Stationery Office, p.20

${ }^{45}$ In Mahon et al's (1998) Women and Crisis Pregnancy: A Report Presented to the Department of Health and Children, Dublin: The Stationery Office, p.19, it is noted that prior to this family planning clinics which prescribed the pill, and made available condoms and diaphragms were established in some regional towns. This study also reveals that there is evidence that contraceptive methods are being used even though contraception is not approved by the Catholic Church.

${ }^{46}$ Tomkin \& Hanafin. (1995) Irish Medical Law, Dublin: Round Hall Press

${ }^{47}$ Mahon, E., Conlon, C. \& Dillon, L.,(1998), Women and Crisis Pregnancy: A Report Presented to the Department of Health and Children, Dublin: The Stationery Office, p.517

${ }^{48}$ Tomkin and Hanafin attribute this stance to the overtly Roman Catholic ethos, which pervades in certain hospitals throughout the Republic of Ireland. Tomkin, D. \& Hanafin, P. (1995) Irish Medical Law, Dublin: Round Hall Press, p.191

${ }^{49}$ The sources referred to are contacts by way of email who are involved within the nursing profession in Ireland. One is a lecturer at Dublin City University; another is a midwife on the National Council for Nursing and Midwifery.

${ }^{50}$ Mahon, E., Conlon, C. \& Dillon, L.,(1998), Women and Crisis Pregnancy: A Report Presented to the Department of Health and Children, Dublin: The Stationery Office, p. 175
} 
While there appears to be differences in opinion regarding the availability of sterilisation in the Republic of Ireland, what is obvious is that sterilisation is not regarded as a contraceptive measure in the same way that it is in the United Kingdom. Certainly in the United Kingdom, sterilisation is viewed as a means of dealing with 'unwanted' conception and birth. This is evident in the use of this terminology in the judgments emanating from the Court of Appeal. What is clear is that by virtue of the availability of contraceptives and sterilisation procedures in Ireland is that, however limited these may be, it is possible for a so-called wrongful conception claim to be brought before the Irish courts with the parents of a child born as a result of a failed sterilisation seeking damages.

As noted above, wrongful birth claims are those brought by the parents of a disabled child born as a result of a failure to detect congenital disabilities at the antenatal screening. It must be considered if the Irish courts make a distinction between cases resulting in the birth of a disabled child and those were the child is 'healthy'. The author submits that it is unlikely that the Irish courts would do so. While the judiciary in the United Kingdom have expressed that they would not perceive the option of adoption or abortion as choices that should be made in the event of an unwanted pregnancy, this will be even more pronounced in relation to abortion due to the illegality of the latter in Ireland. Another factor that will influence such a decision would be the availability of prenatal testing for foetal abnormalities.

Antenatal screening practices are significantly different in Ireland compared to the United Kingdom, especially in relation to screening for foetal abnormalities. Foetal abnormality would not be countenanced as a reason for abortion in Ireland, a position reflected in the level of prenatal screening on offer. Amniocentesis tests and prenatal screening are not readily available in the state; indeed the level of testing offered varies and is very much dependent upon the hospital at which the screening is taking place. ${ }^{51}$ Amniocentesis is available on request if specifically requested, but it is not offered as a matter of routine. This is in contrast to the position in the United Kingdom where not only is such testing available but in April 2001 the U.K. Minister for Public Health, Yvette Cooper, proposed that all women should be offered antenatal screening for Down syndrome by the end of 2004. ${ }^{52}$ Even if amniocentesis or prenatal screening was available, and foetal abnormalities were revealed, doctors will be guilty of an offence if they advocate, or promote abortion unless an argument can be made that there is a real and substantial risk to the mother's life. ${ }^{53}$ Failure to warn of foetal abnormalities would not give rise to

\footnotetext{
${ }^{51}$ For example, amniocentesis is offered in Unit 8, the maternity unit at Holles Street Hospital in Dublin, whereas the Rotunda Hospital maternity unit in Dublin does not offer such testing, and this is attributed to the Church of Ireland ethos of the hospital. Holles Street Hospital, Dublin was the first place to set up a Marriage Guidance Clinic once Pope Pius XII justified use of the safe period - see Mahon, E., Conlon, C. \& Dillon, L.,(1998), Women and Crisis Pregnancy: A Report Presented to the Department of Health and Children, Dublin: The Stationery Office, p.19

${ }^{52}$ National Screening Committee, 'Standards for Antenatal Screening including specific standards for Down syndrome screening’ (August 2003) http://www.nsc.nhs.uk/hottopics/hottopics ind.htm accessed 19th August 2003

${ }^{53}$ For this reason some women choose to have the amniocentesis test done in Northern Ireland or the United Kingdom.
} 
negligence case in Ireland whereas in England it would give rise to an automatic negligence action if such testing were not available, or if a disability was detected and the parents are not informed of the disability. Thus, on this basis it can be concluded that in Ireland, the courts would dismiss claims seeking damages for wrongful birth from the outset.

\section{The Constitutional Impact on Wrongful Conception and Wrongful Birth Actions}

That the child is a blessing is one of the public policy arguments cited by the House of Lords in McFarlane as a reason for not awarding maintenance for a child's upbringing. Indeed it echoes the stance taken in the decision in Udale ${ }^{54}$ whereby Jupp J. rejected a claim for the future costs of rearing a child to the age of sixteen as he held that on consideration of public policy it was undesirable that the child should learn that the court had declared its life to be a mistake. That the child is a blessing and very much wanted by society in Ireland is evident within the provisions of the Constitution of Ireland 1937 as amended. Article 40.3.3 declares that:

"The State acknowledges the right to life of the unborn and, with due regard to the equal right to life of the mother, guarantees in its laws to respect, and, as far as practicable, by its laws to defend and vindicate that right." 55

Costello $\mathrm{J}$ described this Constitutional amendment as a clear 'expression of public policy'. ${ }^{56}$ Subsequent case law relating to procurement of a legal abortion and the ability to travel with the intention to have an abortion elsewhere underlines that not only has the unborn child a right to life but this is a positive right to life to be balanced only when the mother's equal right to life is under threat. ${ }^{57}$

There is some recognition that the birth of a child is not always a welcome addition on every occasion. The availability of contraceptive methods signals that conception may not always be desirable, thus the birth of a child may be unwanted. Indeed the terminology used by Lord Slynn in his judgment in McFarlane is a very clear indicator that in the United Kingdom some births are perceived as unwanted. ${ }^{58}$ Compare this with

\footnotetext{
${ }^{54}$ Udale v. Bloomsbury Area Health Authority [1983] 2 All ER 522

${ }^{55}$ Inclusion of Article 40.3.3 is the result of the first abortion referendum held in Ireland twenty years ago that required this Constitutional amendment. This was held on the $7^{\text {th }}$ September 1983, and was passed by 73 per cent. 'Pro-choice groups to call for clearer legislation on abortion', The Irish Times, $20^{\text {th }}$ August 2003.

${ }^{56}$ Per Costello J. in Attorney General v. X and Others [1992] ILRM 401 at 413

${ }^{57}$ A. and B. v. Eastern Health Board [1998] 1 I.R. 464 at 482

${ }^{58}$ McFarlane v. Tayside Health Board [1999] 3 W.L.R. 1301 at 1311, Lord Slynn states that: The parents did not want another child for justifiable, economic and family reasons; they already had four children. They were entitled lawfully to take steps to make sure that that did not happen, one possible such step being a vasectomy of the husband...It does not seem to me to be necessary to consider the events of an unwanted conception and birth in terms of "harm" or "injury" in its ordinary sense of the words. They were unwanted and known by the health board to be unwanted events. The object of the vasectomy was to prevent them happening. It seems to me that in consequence the wife, if there was negligence, is entitled by way of general damages to be compensated for the pain and discomfort and inconvenience of the
} 
the position in Ireland, as there is some indication within Irish judgments that even though contraception is used to prevent conception; the overall stance is that the birth of a child is welcome, due to the Constitutional provisions in place. In his judgment in McGee, Walsh J. makes the rather striking comment regarding birth control and its use for family planning purposes in relation to population size; in essence indicating that the State could intervene and prevent the use of birth control to maintain or increase the population. ${ }^{59}$ However, availability of such family planning methods has not led to the conclusion that a pregnancy could be described as 'unwanted', as Walsh J points out in his decision in SPUC v. Grogan:

"The qualification of certain pregnancies as being 'unwanted' is...a totally unacceptable criterion."60

In comparison to other jurisdictions, the unborn child has almost unassailable rights in Ireland. Recent proposals by both Houses of the Oireachtas in Ireland contained provisions on suicide that would render the right to life of the pregnant woman to be of less value than that of the foetus. ${ }^{61}$ Essentially the Oireachtas proposed to prevent suicide being cited as a ground for lawful abortion in its jurisdiction. Threat to the life of the pregnant woman, namely suicide, has rendered it permissible for a termination to be carried out in exceptional circumstances in Ireland. Contrast this with the position in Spain where the Spanish Constitution provides for the right to life of the unborn child. Unlike the Irish Constitutional provisions, this is not a positive right of the unborn child; rather the mother's right to life is paramount. From 1985 in Spain it is possible to have an abortion for therapeutic, ethical or eugenic causes. ${ }^{62}$ It is argued that in the event of lawful abortion in Spain, it is permissible to protect only the interests of the mother and not those of the unborn child. ${ }^{63}$ The position of the unborn within Irish society is one of polarity with that of the unborn child in Spain. Not only is there Constitutional protection but the judiciary have declared that the court has a duty to 'defend and vindicate' the right to life of the unborn in the Attorney General v. $X$ case. ${ }^{64}$ Proposed amendments put before the people of Ireland in the abortion referendum in 2002 signalled a move towards

\footnotetext{
unwanted pregnancy and birth and she is also entitled to special damages associated with both - extra medical expenses, clothes for herself and equipment on the birth of the baby. She does not claim but in my view, in principle she would have been entitled to prove compensation for loss of earnings due to the pregnancy and birth.

${ }^{59}$ McGee v. Attorney General [1974] IR 284 at 313

${ }^{60}$ SPUC (Ireland) Ltd v. Grogan [1990] ILRM 350 at 359

${ }^{61}$ Both Houses of the Oireachtas passed the Twenty-Fifth Amendment of the Constitution (Protection of Human Life in Pregnancy) Bill, 2001 which aimed at excluding suicide as a ground for lawful abortion in Ireland, essentially overturning the Supreme Court decision in Attorney General v. X [1992]. The Irish Abortion Referendum was held on $6^{\text {th }}$ March 2002. These proposals have not been given effect due to the 'No' vote in abortion referendum rejecting the Irish government's attempt to remove the threat of suicide as a grounds for legal abortion.

${ }^{62}$ Martin-Casals, M. \& Sole Feliu, J. (2003) ‘Cour de Cassation, 13 Juillet 2001’ European Review of Private Law Vol.11 (2): 201-220 at p. 211.

${ }^{63}$ Martin-Casals, M. \& Sole Feliu, J. (2003) 'Cour de Cassation, 13 Juillet 2001' European Review of

Private Law Vol.11(2): 201-220 at p. 219

${ }^{64}$ Attorney General v. $X$ and Others [1992] ILRM 401 at 404
} 
an even more draconian approach. There is no inkling of any liberalisation of the rights of pregnant women to have the option of abortion in Ireland. ${ }^{65}$

One of the arguments made against allowing claims for wrongful conception is that it may lead to doctors encouraging late abortions. ${ }^{66}$ This situation is not likely to arise in Ireland as abortion is unlawful under sections 58 and 59 of the Offences Against the Person Act 1861 and also under Article 40.3.3 of the Constitution which protects the right to life of the unborn child. Moreover the decision of the Supreme Court in the $X$ case has also had a profound influence on deliberations on this matter. The unborn child has a positive right to life enshrined in the Constitution with the sole exception to this being where the mother's life is at risk, whereby equal regard must be had for the mother's life. Abortion is by no means an 'easy' option ordinarily in Ireland thus the chance of a defensive practice emerging that encourages late abortions is unlikely to arise in the foreseeable future.

Another public policy argument under consideration in such cases is that there would be a huge flux in the number of legal actions taken claiming maintenance for wrongful conception. ${ }^{67}$ In the event of the Irish courts hearing such cases, it is arguable that this will lead to a deluge of potential claimants given that there are a small number of people who could possibly submit a claim, a factor which would be even more pronounced in Ireland than in the United Kingdom for the reasons noted above. ${ }^{68}$ Wrongful birth claims would not have any standing in this jurisdiction as abortion on the grounds of foetal abnormality is not permissible unless there is a real and substantial risk to the life of the mother, which has been outlined in the $X$ case and reiterated by the Supreme Court in Baby $O v$. Minister for Justice. ${ }^{69}$ Even if amniocentesis testing is carried out and congenital abnormalities detected, the parents will not have a right to seek an abortion on the grounds that this child will be born with a disability. Such an action would be dismissed by the Irish courts on the basis of the existing laws in place. There is no duty in Ireland to inform patients about the availability of such prenatal tests therefore no action for negligence for failing to inform the patient about such tests or procedures would be admissible before the courts.

\footnotetext{
${ }^{65}$ One of the proposals in the Twenty-Fifth Amendment of the Constitution (Protection of Human Life in Pregnancy) Bill, 2001 was the introduction of a 12 year penalty for women who terminate their pregnancy in Ireland. The Irish Council for Civil Liberties is particularly critical of both the current position on abortion and of the proposals advocated by the Oireachtas in the 2001 Bill. For further details see http://www.iccl.ie/women/abortion/abortion.paper2002.html

${ }^{66}$ Donnelly, M. (1997) 'The injury of parenthood: the tort of wrongful conception', Northern Ireland Legal Quarterly, Vol.48, No.1 p.10 at p.22

${ }^{67}$ Donnelly, M. (1997) 'The injury of parenthood: the tort of wrongful conception', Northern Ireland Legal Quarterly, Vol.48, No.1 p.10 at p.22

${ }^{68}$ Per Lord Hope, in 1997 there were 8,357 vasectomies and 7,871 female sterilizations carried out in Scotland. Compare this with Ireland, where Mahon et al's submission to the Department of Health and Children in Ireland indicates that sterilisation is not widely available in all health board areas, and even where it is on offer, the cost of sterilisation is prohibitive. See Mahon, E., Conlon, C. \& Dillon, L., (1998), Women and Crisis Pregnancy: A Report Presented to the Department of Health and Children, Dublin: The Stationery Office.

${ }^{69}$ [2002] 2 I.R. 169
} 
Such is the protection accorded to the unborn that a wrongful life claim would not be viable in Ireland. In the Attorney General v. $X$, the Supreme Court underlines its duty 'to defend and vindicate the right to life of the unborn'. Wrongful life actions are those taken by child born with disabilities after sterilisation has failed, or if there has been a failure to detect any congenital abnormalities, seeking damages for having been born. ${ }^{70}$ In such circumstances, the mother would be contending that had she been aware of these congenital abnormalities that she would have terminated the pregnancy. The Supreme Court in Baby $O$ v. Minister for Justice ${ }^{71}$ reiterated that the intention of the Constitutional provision on the right to life was to prevent the legalisation of abortion. Similar to the position in France $^{72}$ and Spain it is inconceivable that such a case would be initiated or that it would lead to damages being granted. ${ }^{73}$ It would not be possible to derive a socalled 'right not to live' from the Constitution of Ireland, such claims simply would not be countenanced in this jurisdiction.

\title{
8. Conclusion
}

The Constitutional right to life will have a significant impact on the outcome of any such cases which may arise. This right will be safeguarded by the judiciary. Judicial attitudes currently perceive the unborn child in Ireland, whether healthy or with disabilities, to be a 'blessing' and not 'unwanted', and as a result compensation is not likely to be awarded in any cases which may try to argue that there is a valid claim for compensation for wrongful conception or wrongful birth cases. Unlike the position in England where the additional costs for maintenance have been awarded on the grounds of disability it is not foreseeable that the Irish courts would not make such an award given that every child is recognised in law as a 'blessing'. Lack of screening for foetal abnormalities further ensures that it is less likely that disability could be invoked as justification for awarding damages; especially as foetal abnormality is not a ground upon which an abortion can be sought in Ireland. While it is clear that McFarlane has made it more difficult to successfully claim compensation, it is even less likely that such claims would be awarded compensation in Ireland.

\author{
Brenda Daly \\ Lecturer in Law, School of Law and Government \\ Dublin City University, Ireland
}

\footnotetext{
${ }^{70}$ This year a court in the Netherlands awarded damages to a disabled child for having been born, in addition to damages being given to her parents for the costs of rearing Kelly Molenaar until she reached the age of 21. See 'Court awards damages to disabled child for having been born', British Medical Journal 2003; 326:784. This decision has led to calls for a ban on such claims; otherwise it is argued that it could lead to greater pressure for more prenatal diagnostic testing from both doctors and parents.

${ }^{71}$ [2002] 2 I.R. 169 at 182

72 As a result of the award made in the Perruche case, a new French Act no.2002-203 of March 2002 relative aux droits des maladies et al la qualite du systeme de sante has been passed prohibiting compensation for wrongful life claims.

${ }^{73}$ See Martin-Casals, M. \& Sole Feliu, J. (2003) 'Cour de Cassation, 13 Juillet 2001' European Review of Private Law Vol.11 (2): 201-220 at p. 211. In this article it is submitted that wrongful birth actions are out of place where legal regulation prohibits abortion.
} 